IZA DP No. 6211

Labour Contracts and Performance of Cameroonian Firms

Benjamin Fomba Kamga

December 2011 


\title{
Labour Contracts and Performance of Cameroonian Firms
}

\author{
Benjamin Fomba Kamga \\ University of Yaoundé II-Soa \\ and IZA
}
Discussion Paper No. 6211
December 2011

\author{
IZA \\ P.O. Box 7240 \\ 53072 Bonn \\ Germany \\ Phone: +49-228-3894-0 \\ Fax: +49-228-3894-180 \\ E-mail: iza@iza.org
}

\begin{abstract}
Any opinions expressed here are those of the author(s) and not those of IZA. Research published in this series may include views on policy, but the institute itself takes no institutional policy positions.

The Institute for the Study of Labor (IZA) in Bonn is a local and virtual international research center and a place of communication between science, politics and business. IZA is an independent nonprofit organization supported by Deutsche Post Foundation. The center is associated with the University of Bonn and offers a stimulating research environment through its international network, workshops and conferences, data service, project support, research visits and doctoral program. IZA engages in (i) original and internationally competitive research in all fields of labor economics, (ii) development of policy concepts, and (iii) dissemination of research results and concepts to the interested public.
\end{abstract}

IZA Discussion Papers often represent preliminary work and are circulated to encourage discussion. Citation of such a paper should account for its provisional character. A revised version may be available directly from the author. 


\section{ABSTRACT}

\section{Labour Contracts and Performance of Cameroonian Firms ${ }^{*}$}

The aim of this study is to evaluate employees' productivity in relation to their contract status. This study uses (a) survey data collected among manufacturing sector firms, having more than 15 employees, in Cameroon between April and May 2006 and (b) information issued by the National Institute of Statistics. Information collected concerned 45 firms spanning the period 2003 to 2005. This study uses the stochastic production frontier, distinguishing employees holding fixed-term contract (FTC) from employees that do not have fixed-term contracts (indefinite-term contract (ITC)). Results are estimated in 2 stages. First, we evaluate the determinants of the utilisation of FTC workers and second, we estimate the level of efficiency and productivity of two types of workers. Empirical results indicate that employees holding FTC are twice more productive than those holding ITC. Likewise, parameters indicating returns to scale are 1.3. This parameter, though not significant, is greater than one indicating constant returns to scale in the firm production function.

JEL Classification: J41, J82, L25

Keywords: labour contract, fixed-term contract, indefinite-term contract, production frontier

Corresponding author:

Benjamin Fomba Kamga

The University of Yaoundé II-Soa

Faculty of Economics and Management

P.O. Box 1792

Yaoundé

Cameroon

E-mail: fomba1@yahoo.fr

\footnotetext{
" I would like to thank Tsafack Nanfosso Roger, Nkamleu Guy Blaise, Epo Boniface, Ndamsa Dickson and Kengne Kamga Arline for their valuable comments. This paper has benefited from the suggestions of participants at the Ad-hoc Expert Group Meeting on Macroeconomics Policy (Addis-Ababa, November 2008), the $4^{\text {th }}$ IZA/World Bank Conference on Employment and Development and the 2009 CSAE conference on African economies.
} 


\section{Introduction}

An analysis of issues associated to Labour markets reveals its capacity to reduce unemployment. According to the neo-classical school, this objective is achieved via the flexibility of wages. These wages are defined following the confrontation of the supply and the demand for labour. Thus, any unemployment is voluntary. It is within the framework of the theories of implicit contracts, wage efficiency, trade unions, minimum wage, and many others that involuntary unemployment will be conceived. This unemployment will be explained by the rigidity of the labour market, which is generally due to the rationality of actors in the labour market. With the inability of wages to suppress unemployment, public policies are oriented towards the reduction of labour costs rather than wages. These policies concern the reduction of taxes associated to the factors of labour, regulation of minimum wage, costs of dismissal and the introduction of fixed-term contracts (FTC) or any other form of precarious employment. These new policies have mixed effects on the macroeconomic results, especially on unemployment (Bertola, 1990; Bentolila and Bertola, 1990; Blanchard and Landier, 2002; Cahuc and Postel-Vinay, 2002). If at the macroeconomic level the consequences of the labour contracts on the job market are debatable, we can ask ourselves how they affect actors of the labour market at the levels of firms (microeconomic level).

Since the end of the 1980s, one of the most important characteristics of labour contracts is its duration. This duration can be fixed or undetermined. Cameroon, especially in 1992, has witnessed reforms relating to labour market. The main objective of the 1992 reform was to improve on the performance of companies. Unfortunately, these reforms resulted in the increase of precarious jobs. The increase in the number of employees under a FTC has been widely studied (Booth et al., 2002a). However, the questions often treated by researchers relate on one the hand to the impact of temporary contracts on unemployment and job creation (Cahuc and Postel-Vinay, 2002; Blanchard and Landier, 2002), and on the other hand, to the 
microeconomic effect of precarious employment on wages, on-the-job training, or the transition from precarious employment to permanent contract in the labour market (D’Addio and Rosholm, 2005; Güell and Petrongolo, 2007). Very few studies have examined the effects of precarious contracts on the performance of companies. Two serious problems arise in relation to two analytical approaches. Whereas the first approach lays emphasis on the effects of FTC on the reduction of production costs (Bertola, 1990; Bentolila and Bertola, 1990; Goux et al., 2001) in order to control uncertainties due to the demand of goods and services, the second focalizes on the stimulating nature of FTC (Ichino and Riphanh, 2001; Engellandt and Riphanh, 2005; Tsafack Nanfosso and Fomba Kamga, 2011). The main objective of this paper is to measure the effect of FTC on the performance of firms in Cameroon, notably its productivity. Specially, this paper seeks to (a) identify the determinants of FTC in Cameroonian firms; (b) compare the productivity of workers under FTC and those under indefinite-term contract (ITC) and; (c) determine the efficiency of Cameroonian firms as well as their return to scale.

This paper contributes to knowledge in three ways. By positioning itself in the extension of microeconomic analysis of labour contracts, especially FTC initiated by Booth et al. (2002), this study is one of the first in developing countries in Africa, situated south of the Saharan. It also adds to the little number of works carried out on microeconomic labour contracts. Likewise, this work uses the production function to evaluate productivity differentials between temporary and permanent workers. Finally, it takes into consideration the endogenous nature of the rate of FTC workers in determining production frontier.

The rest of the paper is organized as follows. Section II reviews labour market reforms and stylistic facts about in Cameroonian firms. Section III outlines the related literature. Section IV presents the methodology, data used in this study and descriptive statistics. Section V indicates results and section VI concludes this study. 


\section{A review of labour market reform and stylistic facts about Cameroonian firms}

\subsection{Labour market reform}

The Labour Code currently in force in Cameroon is the result of a procedure which started since 1952, before independence.

\subsubsection{From the Labour Code of 1952 to the Labour Code of 1974}

After the code of 1952, instituted by colonial authorities, law-makers successively promulgated other codes in 1967, 1974 and 1992. The provisions of previous codes especially that of 1974, are rigid concerning labour contracts. Initially, Article 30 subparagraphs 2 of the 1974 code provided that "if the contract is concluded for a limited duration, this duration cannot exceed two years". As for subparagraph 3, it laid out that "When the two-year period envisaged above is exceeded and employment continues beyond such date, the fixed-term contract becomes an open-ended contract...". The ITC was thus the norm and the FTC an exception. A review of these codes indicate that, conditions for dismissal were constraining, especially in terms of notice, allowances, administrative procedures, among others. The crisis witnessed by Cameroon since the 1980s and the requirements of the various adjustment programs, caused firms not to respect the 1974 code (Tjouen, 1996). Beyond the fact that this code was considered to be rigid, it was often considered by employers as a source of inefficiency. An improvement of the labour market, regarding more flexibility, was desired by

local employers as well as international financial institutions, particularly IMF and the World Bank (Pougoué, 1991).

\subsubsection{The 1992 Labour Code}

The 1992 code was an extension of the wind of liberalism which blew across Africa and Cameroon in particular since 1990, with law n90/093 of December 19, 1990. This code was aimed at improving the flexibility of the labour market and to enhance the competitiveness of firms. This ambition was materialized by modifications related to trade unions, with 
negotiations concerning employment relationships. Thus, the FTC which was an exception in 1974 code became legal, accompanied by employment forms different from permanent contracts or ITC. These forms of employment differ by their duration, their degree of attachment to the firm and their number of renewals.

The 1992 code made it possible for a firm in Cameroon to have these various forms of employment in the following ways:

First, the employees working for the firm without being under its administrative responsibility can either be recruited by a drudge or sub-contractor company. Cameroon Labour Code defines the drudge as a sub-contractor who recruits the necessary labour itself, signs a written contract with a contractor for the execution of a certain task or the provision of certain services for a lump sum payment.

Secondly, temporary work companies are organized by Decree $\mathrm{N}^{\circ} 93 / 572 / \mathrm{PM}$ of July 15 , 1993. These companies provide firms (user enterprises) with employees for a period which should not exceed 12 months, with the possibility of renewing the contract once. The "temporary work contractor" relates to the worker by a labour contract and to the user by a provision contract. The contract between the temporary work company and the user must include the following elements: the reason for the recourse to temporary work; the term of the provision includes, as appropriate, a clause envisaging the possibility of modifying this term, the description of the post to be occupied specifying its characteristics and the needed professional qualification; and the place of execution and schedule. The contract between the employee and the "temporary work company" must be written and the qualification of the employee clearly indicated, compensation details, modes of payment, and the possibility for the user to hire the employee at the end of the labour contract. The worker is not paid by the user but benefits from social protection measures and their wages must take into account the condition of seniority in the temporary work company. 
Thirdly, employees working for the firm under its direct responsibility can either be recruited for an unspecified, a specified period or just for part time. These categories of employees differ on several points: (a) in the degree and the duration with which the administrative control of the firm is exerted. While temporary employees and ITC are under the total administrative control of the employer, part-time employees partly escape this control; (b) part-time employees can have a permanent or temporary status and be perceived as a subgroup of ITC or FTC employees, everything depending on the number of working hours per day/week. Apart from the number of hours of work per day and/or week, relationships with the firm differ by the duration, the written character or not of the contract, and the possibility of becoming permanent.

These changes in negotiation, the conclusion and the performance of labour contracts were followed by changes in the organisation and the functioning of trade unions. The 1992 labour market reform was preceded by the "Neutrality Declaration" of trade union organisation in 1991, which helped distinguish trade union organisations from political parties and public administration. Negotiations relating to work relationships which where directed by the government were henceforth carried out in a tripartite framework. Workers were henceforth expected to negotiate directly with companies without any government intervention, except as an arbitrator.

\subsection{Stylized facts on the Cameroonian industry sector}

After independence in 1960, the industrialization strategy designed to replace importations enabled the Cameroonian manufacturing sector to record a growth rate of 9.7\% between 1961 and 1979 (Tybout et al., 1996). This sector suffered the severe crisis experienced in Cameroon since 1987. The level of employment deteriorated between 1985 and 1992, with a 19\% decline in the food industry and 38\% in the manufacturing industry, although this decline was limited to the exportation of semi-processed products (Cogneau, 1993). At the same time, average growth rates in this sector were negative between 1990 and 1999, ranging from -5\% 
in 1990 to $-1.8 \%$ in 1999 . Table A1 indicates that the contribution of the manufacturing industry to the GDP remained below that of the tertiary sector. From 1993 to 2006, the share of the manufacturing industry in the GDP growth rate remained stable around $12 \%$ while the tertiary sector reached $42 \%$ in 2003 .These results contrasted with those of countries with high growth rates and with a proportion of manufacturing in the growth rate above $30 \%$ such as Botswana, Ghana, China, Brazil and Ecuador (World Bank, 2006).

The workforce in Cameroon has steadily increased since 1993 from 3.8 to 6.5 million between 1993 and 2003. The share of industry in employment is between $10 \%$ and 13\%, while the agricultural sector remains above $60 \%$ as shown in Table A2. Table A3 reveals that private employment grew at an average annual rate of over 5\% between 1993 and 2003, representing approximately $95.8 \%$ of total employment, with only $6.7 \%$ of workers in the formal sector. Formal private employment sector has experienced a steady decline in numbers at an average annual rate of $-7.4 \%$ between 1993 and 2003 due to the reform of the labour market in 1992. Within the same period, the public sector recorded a net loss of 71,000 jobs because of layoffs and hiring freeze. The distribution of payroll by industry reveals that the tertiary sector is the main distributor of wages in Cameroon with $35.7 \%$ of payroll. It is followed by the secondary sector which provides $25.3 \%$ of payroll. The primary sector is last with $7.5 \%$ of payroll. The primary sector, the main provider of employment, at the same time records the lowest wages level; the average annual wage was 280,000FCFA. The secondary sector (tertiary respectively) is 506,000 FCFA (FCFA 611,000 respectively).

\section{Literature review}

Work contracts affects business performance through production cost and the productivity of factors of production. The fixed-term contracts (FTC) allow the company to manage demand fluctuations in consumer goods and services market by minimizing the adjustment ${ }^{1}$ costs of the number of employees (Bentolila and Saint-Paul, 1994). Thus, in periods of expansion, the

\footnotetext{
${ }^{1}$ Adjustment costs include employment and lay-off costs.
} 
firm may hire employees under fixed-terms and they can be dismissed without costs during periods of recession. Beyond this numerical flexibility, FTCs allow the firm to acquire a functional flexibility, which will facilitate access to expensive expertise (Christensen, 1991). Numerical flexibility and functional flexibility allow the firm to manage its payroll and increase profits.

In addition, using workers under FTCs increases the productivity of firms, hence their business performance. In this context, considering their situation as a stepping stone or as an extension of the selection process, FTC employees can be more productive than those on ITC (Ichino and Riphahn, 2005). Notwithstanding, the working conditions of FTC employees are generally very poor with low wages compared to those on ITC (d'Addio and Rosholm, 2005) and generally without any form of social security. These elements result in locating the temporary employees on the secondary market, those having an ITC being on the primary segment. Under such conditions, one admits with the theory of wage efficiency that temporary employees are more willing to skiver, thus reducing their productivity. From the above remark, it is evident that the explanation of the relation labour contracts and performance of the firm via the incentive to produce more efforts cannot be known in advance. The use of temporary employees can be a source of profit or loss of productivity (Ichino and Riphahn, 2005; Tsafack Nanfosso and Fomba Kamga, 2011).

Empirically, the relationship between labour contract and corporate performance has been the subject of several studies. The first group of work focuses on the relationship between FTCs and the minimization of labour costs by using the production cost function. In this logic, Uzzi and Zoe (1998) have showed that the use of an ITC costs twice as much as using a FTC. Bentolila et al. (1994) indicate that an increase by $1 \%$ of the proportion of temporary workers reduces labour costs of $0.64 \%$ in private enterprises in the Italian manufacturing sector. 
The second group of work concerned the relationship between FTCs and effort. Employee productivity is measured by effort, absenteeism and unpaid overtime. In this perspective, Engellandt and Riphahn (2005) using the absentee rate and unpaid overtime confirmed the positive relationship between temporary employees and effort incentive. Booth et al. (2002) by integrating the transition confirmed on a 7-year period that nearly $38 \%$ of temporary employees obtain an ITC at the end of their FTC. Moreover, while they are under a FTC, effort measured by unpaid overtime is higher than when they sign permanent contracts. In the same line, Ichino and Riphahn (2001) observed an increase in the absentee rate among the employees of Italian banks after the probationary period, which is accompanied in this country by a strong protection of employment.

The third group of work measures the performance of the company by the production function in response to the shortcomings of financial performance. ${ }^{2}$ The consideration of resources in the evaluation of performance is done via the production function; which establishes a relationship between the maximum output which can be produced and a set of inputs, given the existing level of technology of the firms. From this function are deduced average productivities of the different factors of production. This approach encounters at least two criticisms. The first is the fact that average productivity relates to only one factor, the others being ignored. On this basis, it becomes difficult to make a ranking of the companies when the rows are reversed from one factor to another. The second is the assumption that production units operate on their production frontier whereas they can be located in the entire production without being on the frontier.

By taking into account the whole set of inputs and outputs at the same time, the calculation of the efficiency index makes it possible to mitigate these failures. These approaches have the

\footnotetext{
${ }^{2}$ Financial measures enable a classification of companies based on their performance, do not communicate enough on the resources used.
} 
advantage that in some cases they can help to obtain at the same time the productivity of the factors and efficiency index. With their values ranging between 0 and 1 , these indexes make it possible to distinguish the most outstanding firms; i.e. those whose efficiency index are closer to the unit of the least impressive; i.e. those whose index are close to 0 . The calculation of the efficiency index can be done from the nonparametric models or the parametric models.

Non-parametric methods have the advantage of not requiring the specification of the functional form of the production function and their main disadvantage is their inability to assess the productivity of different inputs. One of the advantages of parametric methods is that they allow the obtainment of the index of efficiency of the firm and assesses the productivity of production factors. The heterogeneity of production factors, including labour inputs can therefore be taken into account. Mairesse and Cunot (1988), and Mairesse and Sassenou (1989) introduced the heterogeneity of labour across different socio-professional categories in the production function to assess productivity differences between employees in French industries. N'gbo Aké (1994), distinguishing employees based on their participation in the capital of French cooperatives and uses a Cobb-Douglas production function to assess productivity differentials between members staff and non members staff of French cooperatives.

\section{Methodology}

The methodology adopted for this study is based on an econometric estimation of a production frontier whose functional form is specified in advance. Considering the fact that the variability of production is attributable to environmental factors which could not always be managed by firm, this study uses the stochastic frontier method. The stochastic frontiers method makes it possible to estimate a frontier function which simultaneously takes into account the random error and the inefficiency component, specific to every firm. 
The stochastic production frontier method was initially proposed by Aigner et al. (1977), Meeusen and Van der Broeck (1977). Once a functional form has been chosen for the production function, the following model is adopted: $y_{i}=f\left(x_{i}, \beta\right)+\varepsilon_{i}$, where $y_{i}$ is the output obtained by the firm $i, x_{i}$ is the vector of used inputs, $\beta$ is a vector of parameters to be estimated and $\varepsilon_{i}$ is a composed error with two elements, $\varepsilon_{i}=v_{i}+u_{i}$.

The error component $v_{i}$ represents the symmetric disturbance that captures the random variations in production due to factors such as random errors, errors in observation, data measurement and chance. This error component is assumed to be identically and independently distributed as $N\left(0, \sigma_{v}^{2}\right)$. The error component $u_{i}$ is an asymmetric term that captures technical inefficiency, and is assumed to be distributed independently of $v_{i}$, and to satisfy $u_{i} \leq 0$. A statistical distribution for $u_{i}$ has to be assumed. Aigner et al. (1977) analysed the cases of half-normal and exponential distributions. Meeusen and van den Broeck (1977) considered only the latter. In this paper it will be assumed that the random error $u_{i}$ is halfnormally distributed, since it better fits the available data.

\subsection{Consideration of labour contract in modeling}

In spite of the numerous temporary contracts authorised by the 1992 Code, information provided by firms as well as those obtained from the National Institute of Statistics only distinguishes between employees under an ITC and those under a FTC. The theoretical framework used is the production theory because it is assumed that the firm is capable of transforming various inputs into output. The Cobb-Douglas specification is widely used because it generally represents a good description of the production process (Jorgensen, 1972). In addition, algebraic manipulations are easier with the Cobb-Douglas function.

Considering the two main production factors which are capital and labour, and adopting a Cobb-Douglas specification, the production function can be written as follows: 
$\ln y_{i t}=\beta_{0}+\beta_{1} \ln K_{i t}+\beta_{2} \ln L_{i t}+v_{i t}-\mu_{i}$

Where $y_{i t}$ is the output of firm $i$ at period $t ; K_{i t}$ measures the firm's capital $i$ at period $t$, $L_{i t}$ measures the effective labour used by firm $i$ at period $t ; \beta$ indicates the vector of the production frontier to be estimated, $v_{i t}$ is the symmetric error term such as $v_{i t} \rightarrow N\left(0, \sigma_{v}^{2}\right) ; \mu_{i}$ is the error term representing technical inefficiency and assumed invariant in time such that $\mu_{i} \rightarrow N\left(0, \sigma^{2}\right)$. Given that the labour force is made of employees whose labour contracts with the firm are different, the effective labour factor is split into two sub-groups which are: employees under ITC and those under FTC.

$$
L_{i t}=N_{i t}^{i t c}+\delta N_{i t}^{f t c}
$$

Where $\delta$ measures a FTC equivalent in ITC. $0<\delta<1$ because it is assumed that employees under FTC are less productive than those under ITC. In equation (2) $N_{i t}^{i t c}$ and $N_{i t}^{f t c}$ are the number of workers under ITC and FTC in firm $i$ at period $t$ respectively. Let $T_{i t}^{\text {ftc }}$ be the proportion of workers under FTC, and is expressed by:

$T_{i t}^{f t c}=\frac{N_{i t}^{f t c}}{N_{i t}}$

Let $N_{i t}$ be the number of ITC and FTC in firm $i$ at period $t$, it's expressed as follow:

$$
N_{i t}=N_{i t}^{i t c}+N_{i t}^{f t c}
$$

Substituting (4) in (2) the effective labour factor according to $N_{i t}, N_{i t}^{f t c}$ and $\delta$ is given by:

$$
L_{i t}=N_{i t}+(\delta-1) N_{i t}^{f t c}
$$

Substituting (3) in (5) the expression of effective labour factor according to $N_{i t}, T_{i t}^{f t c}$ and $\delta$ is no expressed as: 


$$
L_{i t}=N_{i t}\left[1+(\delta-1) T_{i t}^{f t c}\right]
$$

The linearization of this expression gives:

$$
\ln L_{i t}=\ln N_{i t}+\ln \left[1+(\delta-1) T_{i t}^{f t c}\right]
$$

Assuming $T_{i t}^{f t c}$ to be very small, the second term of equation (7) is close to $(\delta-1) T_{i t}^{f t c} 3$.

Therefore, equation (7) now becomes:

$$
\ln L_{i t}=\ln N_{i t}+(\delta-1) T_{i t}^{f t c}
$$

Substituting (8) in (1), the production frontier function to be estimated is given by:

$$
\ln y_{i t}=\beta_{0}+\beta_{1} \ln K_{i t}+\alpha_{1} \ln N_{i t}+\alpha_{2} T_{i t}^{f t c}+\varepsilon_{i t}
$$

Where $\alpha_{1}=\beta_{2}$ and $\alpha_{2}=\beta_{2}(\delta-1)$

$\delta=\frac{\partial y_{i t}}{\partial N_{i t}^{f t c}} / \frac{\partial y_{i t}}{\partial N_{i t}^{i t c}}$ is therefore the relation between the marginal productivity of workers under FTC and those under ITC and its expression is given by:

$$
\delta=1+\frac{\alpha_{2}}{\beta_{2}}
$$

\subsection{Endogeneity of the FTC Rate}

The number of temporary employees in the firm is subject to an economic calculation and can face particular constraints as shown in the literature review. Thus, the rate of temporary employees can’t be considered as an exogenous variable. To solve this problem, we purge out potential endogeneity between the rate of FTC employment and other variables. The second step consists in obtaining the predicted values of the rate of FTC employment in each firm. These values are inserted in equation (9) to replace the FTC variable. As the temporary employee rate in each firm is comprised between 0 and 1, its modelling is done using

\footnotetext{
${ }^{3}$ When $x$ is small, $\ln (1+x) \approx x$.
} 
truncated Tobit model. Variables used to estimate the determinants of precarious employees are discussed by Mangun et al. (1985), Davis-Blake and Uzzi (1993), Betcherman et al.(1994), Casey (1988), Byoung-Hoon Lee et al. (2005). Figure 1 is a synthesis of these factors.

\section{Figure 1: Factors explaining the utilisation of temporary employment}

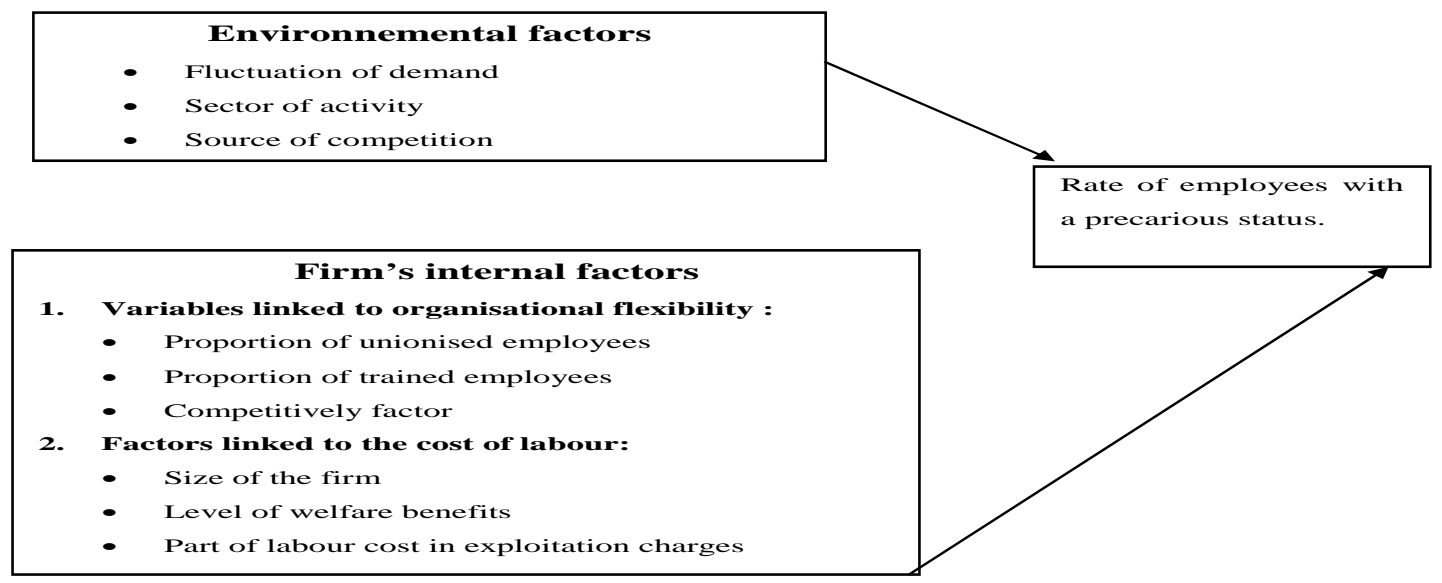

Source: Author from Mangun et al. (1985) and Byoung-Hoon Lee et al. (2005)

\subsection{Data, Definition and Descriptive Statistics of Variables Used}

The data used in this paper comes from the survey entitled "Working conditions in the manufacturing industry in Cameroon" conducted in 2006 with funding from the African Economic Research Consortium (AERC) as part of the Collaborative PhD Programme. The survey focused on enterprises in the cities of Yaoundé and Douala with at least 15 employees. The quota sampling method is adopted to determine the number of firms and employees in each city and firm. The companies were selected from the directory of Cameroonian businesses available at the National Institute of Statistics (NIS). After processing the data, a sample of 65 companies and 1,809 employees was selected. Concerning this study, only information on 45 firms spread on 3 years (2003, 2004 and 2005) was used. This data was completed by information obtained from the National Institute of Statistics. Firms excluded from our analysis are those whose data were not available over the three-year study period. Retention rates are $78 \%$ for "employee questionnaires" and $80 \%$ for "company 
questionnaires". The distribution of 65 firms surveyed shows that $29.24 \%$ of companies operate in the chemical sector, $23.07 \%$ in food and textile industries; $27.69 \%$ in the plastic and paper and 20\% in the engineering sector. This distribution of 45 firms used in this paper shows that $28.89 \%$ of companies operate in the chemical sector, $28.89 \%$ in food and textile industries; $28.89 \%$ in plastic and paper and $13.33 \%$ in the engineering sector.

\section{Definition and summary Statistics of the variables in the data Set}

Output is captured by the annual turnover of the firm expressed in CFA francs. For inputs, they include labour and capital (the value of the entire available fixed assets at the end of the fiscal year). In addition to these variables, we have the intensity of temporary employees', the proportion of trained workers, the number of union strikes, staff expenses, syndicated workers, sectors of activity, and the turnover index. The turnover index deserves a special attention.

The turnover index captures fluctuations in demand. This variable verifies if variations in the demand of goods and services prompts employers to a greater use of workers with a precarious labour contract. As emphasized by Mangum and al. (1985), Abraham (1988) and Maniscalco (1995), measuring fluctuations in demand through the difference between demands observed on two consecutive periods, leads to "loose” variables and observations on one year. But, using the turnover index avoids this scenario. The expression of the turnover index is given by:

turnover_index $=\left\{\begin{array}{l}1 \text { if } t=1 \\ \frac{y_{t+1}}{y_{t}} \text { if } t=2 \text { or } t=3\end{array}\right.$ where $y_{t}$ is turnover at period $t$.

The turnover index confirms the properties of a simple index and can be used in measuring the evolution of demand.

Table 1 presents a summary of the variables used in this study. The average logarithm of turnover over the period is 21.1717 with a 17.6823 and 25.1891 being the minimum and maximum values, respectively. The logarithm of capital averaged 19.7856 with a maximum 
of 25.5222 which occurred in 2003 and the minimum of 12.9147 in 2004 . The logarithm of the number of workers ranged from 2.1972 to 7.8180 with an average of 4.4615 . Index of turnover is equal to 1 for every firm in 2003 and is ranged from 0.0875 to 17.5792 which indicate that some firms registered an increase in their turnover while others registered a decrease. The extreme values of the turn over index were observed for firms in the food industry. Average staff expenses range from 487.500 to 0.0422 million with an average of 143.204 millions. We observe that variability of average staff expenses between firms is close to the overall variability of average staff expenses. This value was 11.502 millions.

Table 1: Summary statistics for variables in data set

\begin{tabular}{|c|c|c|c|c|c|c|}
\hline Variable & $\begin{array}{l}\text { Definition } \\
\text { variables }\end{array}$ & Observations & Mean & S.D. & Min & Max \\
\hline $\log (Y t)$ & $\begin{array}{l}\text { Logarithm of } \\
\text { turnover. }\end{array}$ & $\begin{array}{l}N=135 \\
N=45 \\
T=3\end{array}$ & 21.1717 & $\begin{array}{l}1.5914 \\
1.5699 \\
0.3236\end{array}$ & $\begin{array}{l}17.6823 \\
17.9759 \\
20.1579\end{array}$ & $\begin{array}{l}25.1891 \\
24.0671 \\
23.112\end{array}$ \\
\hline $\log (\mathrm{Kt})$ & Logarithm of capital. & & 19.7856 & $\begin{array}{l}2.3751 \\
2.3859 \\
0.1828\end{array}$ & $\begin{array}{l}12.9147 \\
13.2201 \\
19.1224\end{array}$ & $\begin{array}{l}25.5222 \\
25.4173 \\
20.8984 \\
\end{array}$ \\
\hline $\log (\mathrm{Lt})$ & Logarithm of labour & & 4.4615 & $\begin{array}{l}1.1579 \\
1.1487 \\
0.2026\end{array}$ & $\begin{array}{l}2.1972 \\
2.4026 \\
3.5317\end{array}$ & $\begin{array}{l}7.8180 \\
7.5532 \\
5.0785\end{array}$ \\
\hline $\begin{array}{l}\text { Indexe of } \\
\text { turnover }\end{array}$ & Index of turnover & & 1.1781 & $\begin{array}{l}1.4840 \\
0, \\
1.2209\end{array}$ & $\begin{array}{l}0.0875192 \\
0.7503768 \\
-4.378734\end{array}$ & $\begin{array}{l}17.5792 \\
6.5568 \\
12.2004\end{array}$ \\
\hline $\begin{array}{l}\text { Proportion of } \\
\text { FTC/year }\end{array}$ & $\begin{array}{l}\text { Proportion of workers } \\
\text { under FTC }\end{array}$ & & 0.4165 & $\begin{array}{l}0.3003 \\
0.2991 \\
0.0457\end{array}$ & $\begin{array}{l}0 \\
0 \\
0.2868\end{array}$ & $\begin{array}{l}1 \\
1 \\
0.6201\end{array}$ \\
\hline $\begin{array}{l}\text { Rate of trained } \\
\text { workers }\end{array}$ & $\begin{array}{l}\text { Proportion of trained } \\
\text { workers. }\end{array}$ & & 0.2570 & $\begin{array}{l}0.2719 \\
0.2707 \\
0.0414\end{array}$ & $\begin{array}{l}0 \\
0 \\
0.0903\end{array}$ & $\begin{array}{l}1 \\
1 \\
0.5659\end{array}$ \\
\hline $\begin{array}{l}\text { Rate of } \\
\text { unionised } \\
\text { workers }\end{array}$ & $\begin{array}{l}\text { Proportion of } \\
\text { unionised workers. }\end{array}$ & & 0.376531 & $\begin{array}{l}0.2578266 \\
0.2581274 \\
0.0289704\end{array}$ & $\begin{array}{l}0 \\
0 \\
0.247743\end{array}$ & $\begin{array}{l}1 \\
1 \\
0.565925\end{array}$ \\
\hline Strikes & $\begin{array}{l}\text { Number of strikes } \\
\text { during the last five } \\
\text { years. }\end{array}$ & & 0.4666 & $\begin{array}{l}1.0059 \\
1.0135 \\
0\end{array}$ & $\begin{array}{l}0 \\
0 \\
0.4666\end{array}$ & $\begin{array}{l}4 \\
4 \\
0.4666\end{array}$ \\
\hline Staff expenses & $\begin{array}{l}\text { Average staff } \\
\text { expenses }\end{array}$ & & $143,204.5$ & $\begin{array}{l}77,973.74 \\
77,702.71 \\
11,502.53\end{array}$ & $\begin{array}{l}42,272.92 \\
44,112.06 \\
93,204.48\end{array}$ & $\begin{array}{l}487,500 \\
420,557.3 \\
243,204.5\end{array}$ \\
\hline
\end{tabular}

Source: Computed based on Survey and NIS data 
The number of strikes recorded during the last five years ranges from 0 to 4 , and the variability of this number in the same company is null.

Table 1, shows that some firms use exclusively temporary workers while others use only permanent workers. The average proportion of temporary workers is 0.4165 and the rate of variability of workers under FTC in firms is 0.0457 . Also, the proportions of employees having received some training sponsored by the firm or being a member of a trade union vary between 0 and 1 with an average of 0.2570 and 0.3765 respectively. In general, typical gaps show that intra-firm variations of variables are weak while inter-firm variations are high.

\section{Results and discussions}

\subsection{Determinants of the intensity of FTC utilisation}

Among explanatory variables used to identify determinants of the temporary worker, only the variable logarithm of the number of workers is used to estimate production frontier. This indicates the identification of our model. The results for identifying determinants of the use of temporary workers are presented in Table 2. Results of the Tobit model are globally significant at $1 \%$ and six variables enable us to explain the intensity of temporary employees’ utilisation. These variables are: the membership rate, proportion of trained workers, average staff expenses, and firms located in Douala, the plastic and paper sector of activity and the metallic sector. Consequently, the model does not suffer from the identification problem. The rate of unionization has a negative and significant effect on the utilization rate of temporary employees. However, this effect decreases at an increasing rate.

These results close to those of Houseman (2001), justify the fact that the insiders limit the recruiting of precarious employees since they can reduce their power of negotiation. In the same way, it appears that when the proportion of trained employees increases, the intensity of the use of temporary employees decreases. Indeed, the increase of $1 \%$ of the rate of trained employees’ decreases by $45.88 \%$ the proportion of temporary employees used by the firms. This result justifies the fact that firms try to keep away from problems associated to holdup. 
Indeed, for firms to make profitable the investments carried out within the scope of training temporary employees can be incited to sign ITC with them.

Table 2: Tobit model of determinants of the intensity of FTC utilisation

\begin{tabular}{|c|c|}
\hline Variables & FTC rate \\
\hline Log of labour & $-0.0183(-0.91)$ \\
\hline Index of turnover & $0.0058(1.37)$ \\
\hline Membership rate & $-0.8754(-2.88) *$ \\
\hline Squared membership rate & $0.3978(1.16)$ \\
\hline Proportion of trained workers & $-0.2130(-2.11) * *$ \\
\hline Average staff expenses & $-7.10^{-7}(-1.87) * * *$ \\
\hline Union strike & $0.0044(0.14)$ \\
\hline Douala & $-0.1601(-1.60) * * *$ \\
\hline \multicolumn{2}{|l|}{ Sectors of activities } \\
\hline Food & $-0.0475(-0.58)$ \\
\hline Plastic and paper & $-0.1794(-2.34) * *$ \\
\hline Metallic & $-0.2452(-2.67) *$ \\
\hline Constant & $1.1455(7.24) *$ \\
\hline Sigma_u & $0.1755(7.52) *$ \\
\hline Sigma_e & $0.0598(12.08) *$ \\
\hline Rho & $0.8960(28.54) *$ \\
\hline Number of observations & 135 \\
\hline Number of firms & 45 \\
\hline Number of period & 3 \\
\hline Log likelihood & 98.827513 \\
\hline Wald chi2 (10) & 78.05 \\
\hline Prob>chi2 & 0.0000 \\
\hline
\end{tabular}

Note: 1 . t-statistics in parentheses.

2. *, ** and *** represent statistical significance at the $1 \%, 5 \%$ and $10 \%$ respectively.

The increase in the level of wages and welfare benefits (measured by the average of staff expenses) decreases the use of temporary employees. This result is in conformity with those of Mangum and al. (1985), Harrison and Kelley (1993), and of Abraham and Taylor (1996). Indeed, the more the company offers labour wages and competitive welfare benefits, the more it will tend to resort to atypical labour contracts. The idea of the reduction of the salary costs is thus confirmed.

The companies located in the town of Douala (relatively to those located in Yaoundé) have a low propensity to use temporary employees. It is the same for industries in the plastic and paper sector, and the metal sector. This result can be justified by the fact that firms in this 
sector have a stable activity, that is, less subjected to competition or that the qualifications required for its operation requires that employments be stable. From this estimate, we obtain the predicted values of the intensity of temporary employees' utilization. These predicted values are used in the estimation of the production frontier.

\subsection{Employees' productivity}

Table 3 reports the uncorrected Maximum Likelihood Estimates (MLE) averaged-firm model $^{4}$, the corrected MLE averaged-firm model, the uncorrected production frontier function estimates and the corrected production frontier function estimates using STATA software and maximum likelihood method. The values of $\mu$ are statistically equal to zero and the variance statistically different from zero, insuring that $\mu_{i} \rightarrow N\left(0, \sigma_{\mu}^{2}\right)$ and $v_{i t} \rightarrow N\left(0, \sigma_{v}^{2}\right)$ as indicated in the methodology. The individual coefficients of the Cobb-Douglas stochastic frontier production function and of the Cobb-Douglas MLE averaged-firm model production function are directly interpretable as partial elasticities of the mean value of output with respect to inputs. They permit the evaluation of the impact of a change in the quantity of an input on output. Partial elasticity values obtained indicate the relative importance of labour and capital in the firm's total production. It can be observed from Table 3 that the factor capital is more important than labour in the firm's production. This result isn't surprising since the manufacturing sector implies transformation, therefore necessitating more capital. The parameter indicating returns to scale vary from 1.3106 for uncorrected MLE averagedfirm model production function estimates to 1.3208 for corrected stochastic frontier production function. This value being mathematically greater than one but statistically equal

\footnotetext{
${ }^{4}$ In this estimation, the temporal dimension is weak. In such a case, the results of the model with random effects are better than those the model with fixed effects. Moreover, intra-firm variations are weaker than inter-firm variations of variables and temporary workers use rate does not change much from one period to another.
} 
to one ${ }^{5}$ indicates constant returns to scale in firm production. The implication of such a result is that, doubling the amount of each input results in a doubling in the quantity produced. This result further reveals that manufacturing firms cannot benefit from economy of scale linked to increasing returns in order to boost production. Different results were obtained by Ajibefun et al. (1996), Ajibefun and Daramola (2003) in their studies on smallholder croppers and microenterprises in the Nigerian economy and by Nchare (2005) in his study on coffee producers in Cameroon.

Differences in productivity between ITCs and FTCs can be analysed through the $\delta$ coefficient, obtained from $\alpha_{2}$ and $\beta_{2}$ as shown in equation (10). The variables Labour and rate of FTC are jointly significant at $1 \%$ as shown in table 3 although partial elasticity of rate of FTC is insignificant. We can therefore compute the differences in productivity between ITC and FTC. Results of $\delta$ are reported in the last line of Table 3. The values of $\delta$ vary from 2.2270 for uncorrected MLE averaged-firm model production function estimates to 2.2362 for corrected stochastic frontier production function estimated. $\delta$ is always greater than one. These results show that employees' holders of FTC are twice more productive than that holding ITC and the difference in productivity is greater when firm operates on the frontier production function, and estimations are corrected from endogeneity of rate of temporary employees used by the firm.

The estimated values of the variance $\gamma=\frac{\sigma_{u}^{2}}{\sigma_{u}^{2}+\sigma_{v}^{2}}$ of the Cobb-Douglas stochastic production frontier function is 0.7595 for uncorrected stochastic production frontier function estimates and 0.7624 for corrected stochastic production frontier function estimates. Their

\footnotetext{
${ }^{5}$ The hypothesis test $H_{0}: \beta_{1}+\alpha_{2}+\beta_{2}=1 / H_{1}: \beta_{1}+\alpha_{2}+\beta_{2} \neq 1$ shows that $\chi_{1}^{2}=0.72, \chi_{1}^{2}=0.35$, $\chi_{1}^{2}=0.72$ et $\chi_{1}^{2}=0.36$ for uncorrected OLS, corrected OLS, uncorrected and corrected stochastic production frontier function, meaning that $H_{0}$ is accepted that is $\beta_{1}+\alpha_{2}+\beta_{2}=1$.
} 
values are not close to one and are significantly different from zero at $1 \%$ level. This finding suggests some technical inefficiency in firm production.

Table 3: MLE for the parameters of the stochastic production frontier

\begin{tabular}{|c|c|c|c|c|}
\hline Variables & $\begin{array}{l}\text { Uncorrected OLS } \\
\text { estimation }\end{array}$ & OLS estimation & $\begin{array}{c}\text { Uncorrected } \\
\text { stochastic frontier } \\
\text { production }\end{array}$ & $\begin{array}{l}\text { Corrected Stochastic } \\
\text { frontier production }\end{array}$ \\
\hline Log (labour) & 0.3682 (3.93) & $0.3732(3.94) *$ & $0.3679(3.91) *$ & $0.3729(3.93) *$ \\
\hline Log (capital) & $0.4906(9.21) *$ & $0.4867(8.88) *$ & $0.4908(9.19) *$ & $0.4869(8.85) *$ \\
\hline FTC/labour & $0.4518(1.34)$ & $0.4590(0.92)$ & $0.4531(1.34)$ & $0.4610(0.92) *$ \\
\hline Constant & $9.6334(9.82) *$ & $9.6797(8.91) *$ & $11.9873(5.63) *$ & $12.0742(5.33) *$ \\
\hline Number of observation & 135 & 135 & 135 & 135 \\
\hline Number of firms & 45 & 45 & 45 & 45 \\
\hline Number of time period & 3 & 3 & 3 & 3 \\
\hline $\mathrm{mu}$ & & & 2.3568 (1.28) & $2.3981(1.24)$ \\
\hline Sigma square & $0.6441(8.27) *$ & $0.6500(8.15) *$ & $0.5474(5.40) *$ & $0.5553(5.32) *$ \\
\hline Sigma_u ${ }^{2}$ & $0.3629(13.20) *$ & $0.3633(13.10) *$ & $0.4158(4.09) *$ & $0.4234(4.03) *$ \\
\hline Sigma_v ${ }^{2}$ & & & $0.1316(6.60) *$ & $0.1320(6.55) *$ \\
\hline Gamma & $0.7590(13.87) *$ & $0.7620(13.77) *$ & $0.7595(13.77) *$ & $0.7624(13.67) *$ \\
\hline Rho & -107.5193 & -107.9931 & & \\
\hline Log likelihood & & & -107.5158 & -107.9900 \\
\hline Return to scale & 1.3106 & 1.3189 & 1.3118 & 1.3208 \\
\hline $\begin{array}{l}\text { Wald test for joint } \\
\text { significance of labour } \\
\text { terms }\end{array}$ & $\operatorname{chi} 2(2)=17.02 *$ & $\operatorname{chi} 2(2)=15.85 *$ & $\operatorname{chi} 2(2)=16.97 *$ & $\operatorname{chi} 2(2)=15.79 *$ \\
\hline$\delta$ & 2.2270 & 2.2299 & 2.2316 & 2.2362 \\
\hline
\end{tabular}

Note: 1 . t-statistics in parentheses.

2. * represents statistical significance at the $1 \%$ level.

The efficiency index obtained from estimating the model represented by equation (9) using maximum likelihood method is grouped together in Table A4 in the appendix. They vary from one firm to another and range from 0.0256 to 0.5774 for uncorrected model with a mean of 0.1218 and from 0.0216 to 0.5723 for corrected model with a mean of 0.1136 . According to these results, more than $80 \%$ of firm output is lost, on average, due to the specific inefficiencies pertaining to firms. The comparison of efficiency index between different sectors shows that chemical, food and mechanical industries have approximately the same efficiency levels in the corrected model as well as in the uncorrected model. The plastic sector is therefore the least efficient. 
Table 4: Distribution of efficiency by sectors

\begin{tabular}{l|c|c|c|c|c|c|c|c|c|c}
\hline & \multicolumn{5}{|c|}{ From uncorrected model } & \multicolumn{5}{c}{ From corrected model } \\
\hline \hline & Chemical & Food & Plastic & Mechanic & All & Chemical & Food & Plastic & Mechanic & All \\
\hline Mean & 0.1387 & 0.1286 & 0.077715 & 0.1375 & 0.1180 & 0.1340 & 0.1218 & 0.0752 & 0.1347 & 0.1136 \\
\hline SD & 0.1364 & 0.0755 & 0.033925 & 0.0601 & 0.0914 & 0.1356 & 0.0682 & 0.0330 & 0.0595 & 0.0890 \\
\hline Min & 0.0412 & 0.0476 & 0.0256 & 0.0429 & 0.0256 & 0.0389 & 0.0467 & 0.0216 & 0.0381 & 0.0216 \\
\hline Max & 0.5774 & 0.3436 & 0.1494 & 0.2304 & 0.5774 & 0.5723 & 0.3054 & 0.1400 & 0.2091 & 0.5723 \\
\hline Quartile 1 & 0.0453 & 0.0848 & 0.0606 & 0.1162 & 0.0628 & 0.0439 & 0.0729 & 0.0559 & 0.1136 & 0.0590 \\
\hline Quartile 2 & 0.1101 & 0.1050 & 0.0725 & 0.1263 & 0.1050 & 0.1008 & 0.1098 & 0.0704 & 0.1231 & 0.0961 \\
\hline Quartile 3 & 0.1600 & 0.1526 & 0.0884 & 0.1831 & 0.1405 & 0.1469 & 0.1480 & 0.0871 & 0.2015 & 0.1400 \\
\hline \hline
\end{tabular}

Source: Computed based on Survey and NIS data

\section{Conclusion}

The study of the effects of employment contracts on the performance of manufacturing firms in Cameroon was made with a sample of 45 firms observed over three years. To do this, a two-step methodology was adopted with a view to correct the endogeneity of usage rate of precarious employees. The first step was to analyze the determinants of the usage of precarious employees and the obtainment of the predicted value of the utilization of precarious employees. In the second step, the estimation of the stochastic frontier of production function was done using the predicted values of precarious employees use rate. This methodological approach was used to calculate (i) the productivity differential between the two types of employees, (ii) returns to scale, and (iii) efficiency levels of firms in the sample.

Empirical results showed that precarious employees are two twice more productive than permanent employees. Returns to scale are constant and firms are technically inefficient. Efficiency index values range from 0.02 to 0.57 for the unadjusted model and 0.03 to 0.58 for the adjusted model. The average efficiency index is statistically the same in the chemical, food and mechanical sectors and is therefore lower in the plastics industry. Industries of the manufacturing sector can therefore increase their production by more than $80 \%$ on average if they are on their efficiency frontier. Based on these results, further studies are needed to 
determine the factors explaining the ineffectiveness of the manufacturing sector. However, it is essential to note that these companies must improve their managerial skills in order to obtain increased return to scale in order to have their size grow alongside their performance.

\section{References}

Abraham, K.G. (1988) 'Flexible staffing arrangements and employers' short-term adjustment strategies', In Hart, R.A. (eds.), Employment, Unemployment, and Labour Utilization: 288311. London: Unwind Hyman.

Abraham, K.G. and Taylor, S.K. (1996) 'Firms' use of outside contractors: theory and evidence', Journal of Labor Economics, 14: 394--424.

Aigner, D.J.; Lowell, C.A.K. and Schmidt P. (1977) 'Formulation and estimation of stochastic frontier production function models', Journal of Econometrics, 6: 21--37.

Ajibefun, A.I., Battese, G.E. and Daramola, A.G. (1996) 'Investigation of factors influencing the technical efficiencies of smallholder croppers in Nigeria', CEPA Working Paper $N^{\circ}$ 10/96, Department of Econometrics, University of New England, Armidale, Australia.

Ajibefun, I.A. and Daramola, A.G. (2003) 'Efficiency of micro-enterprises in the Nigerian Economy’, AERC Research Paper 134, Nairobi: African Economic Research Consortium.

Bentolila, S. and Bertola, G. (1990) 'Firing costs and labor demand: how bad is eurosclerosis? ', Review of Economic Studies, 57: 381--402.

Bentolila, S.; Donaldo, J.J.; Wolfgang F. and Pissarides, C. (1994) 'Labour flexibility and wages: lessons from Spain’, Economic Policy, 54--99.

Bentolila, S. et Saint-Paul, G. (1994) 'A model of labor demand with linear adjustment costs’, Labour Economics, 1: 303--326.

Bertola, G. (1990) 'Job security, employment and wages', European Economic Review, 34: 851--886. 
Betcherman, G.; McMullen, K.; Leckie, N. and Caron C. (1994) The Canadian workplace in transition, Final Report of the Human Resource Management Project. Kingston: IRC Press. Blanchard, O. and Landier, A. (2002). 'The perverse effects of partial labour market reform: fixed-term contracts in France', Economic Journal, 112: 214--244.

Booth, A.; Francesconi, M. and Frank, J. (2002) 'Temporary jobs: stepping stones or dead ends? ', Economic Journal Features, Symposium on Temporary Work, 189--213.

Buchholtz, A.K.; Ribbens, B.A. and Houle, I.T. (2003) 'The role of human capital in post acquisition CEO departure', Academy of Management Journal, 46: 506--514.

Byoung-Hoon, L., Dong-Bae, K. and Joonmo, C. (2005) 'Union effect on the use of nonregular labor in the Republic of Korea’, The Developing Economies, XLIII: 425--449.

Cahuc, P. and Postel - Vinay, F. (2002) 'Temporary jobs, employment protection and labor market performance', Labour Economics, 9: 63--91.

Casey, B. (1988) 'The extent and nature of temporary employment in Britain', Cambridge Journal of Economics, 12: 487--509.

Christensen, K. (1991) 'The two-tiered workforce in US corporations', In Doeringer, P.B. (ed.) 140--155, Tuberculence in the American Workplace, Oxford University Press.

Cogneau, D. (1993) 'L’industrie camerounaise dans la crise 1984-1992’, Étude DIAL-DSCN. D’Addio, A.C. and Rosholm, M. (2005) 'Exits from temporary jobs in Europe: a competing risks analysis’, Labour Economics, 12: 449--468.

Davis-Blake, A. and Uzzi, B. (1993) 'Determinants of employment externalization: a study of temporary workers and independent contractors', Administrative science quarterly, 38: 195--223.

Engellandt, A. and Riphahn, R.T. (2005) 'Temporary contracts and employee effort', Labour Economic, 12: 281--299. 
Goux, D.; Maurin, E. and Pauchet, M. (2001) 'Fixed - term contracts and the dynamics of labour demand', European Economic Review, 45: 533--552.

Güell, M. and Petrongolo, B. (2007) 'How binding are legal limits? Transitions from temporary to permanent work in Spain', Labour Economics, 14: 153--183.

Harrison, B. and Kelley, M.R. (1993) 'Outsourcing and the search for flexibility’, Work, Employment and Society, June: 213--235.

Houseman, S. (2001) 'Why employers use flexible staffing arrangements: evidence from an establishment survey’, Industrial and labor relations review, 55: 149--170.

Ichino, A. and Riphahn, R.T. (2001) 'The effect of employment protection on worker effort: a comparison of Absenteeism during and after Probation', IZA Discussion Paper, 385: 1--18. Institut National de la Statistique (2005) Enquête sur l'Emploi et le Secteur Informel au Cameroun, premiers indicateurs phase1, Mimeo.

Jorgenson, D.W. (1972) ‘Investment behaviour and the production function’, Bell Journal of Economics and Management Science, 3.

Loi n 92/007 du 14 Août 1992 portant Code du Travail du Cameroun.

Mairesse, J. and Cuneo, P. (1985) 'Recherche-développement et performances des entreprises. Une étude économétrique sur données individuelles', Revue Économique, 5 : 1001--1041.

Mairesse, J. and Sassenou, M. (1989) 'Les facteurs qualificatifs de la productivité : un essai d'évaluation', Économie et Prévision, 91 : 35--42.

Mangum, G.; Mayall, D. and Nelson, K. (1985) 'The temporary help industry: a response to the dual internal labor markets', Industrial and labor relations review, 38: 599--611.

Maniscalco, R. (1995) 'The employment staffing alternative', Information Systems Management, 12: 66--68. 
Meeusen, W. and Van den Broeck J. (1977) 'Efficiency Estimation from Cobb - Douglas

Production Function with Composed Error', International Economic Review, Vol. 18.

Nchare, A. (2005) 'Technical efficiency and returns to scale in agriculture: the case of Arabica coffee producers in Cameroon', African Journal of Economic Policy, 12: 89--111.

N’gbo Aké, G.M. (1994) 'L’efficacité productive des scops françaises: estimation et simulation à partir d'une frontière de production stochastique', Revue économique, 45 : 115-128.

Pougoué, P.G. (1991). La flexibilité du marché du travail et la protection de l'emploi au Cameroun. Mimeo.

Tjouen, A. (1996) 'De la participation du personnel à la gestion des entreprises en droit camerounais: La Problématique des Comités d'Entreprise', Revue Internationale de Droit Comparé, 2 : 455--470.

Tsafack Nanfosso, R. and Fomba Kamga, B. (2011) 'Labour contracts and shirking in Cameroon’ International Journal of Economics and Finance, 3: 35--43.

Tybout, J., Gauthier, B., Navaretti, G.B. and De Melo, J. (1996) 'Réponse des entreprises camerounaises à la dévaluation', Revue d’Économie du Développement, 4 : 5--39.

Uzzi, B. and Zoe, I. (1998) 'Contingent employment in British establishments: organizational determinants of the use of fixed-term hires and part-time workers' Social forces, 76: 967-1007.

World Bank (2006). World Bank development indicators.

Table A1: Contribution of sectors to current GDP (\%)

\begin{tabular}{l|c|c|c|c|c|c|c|c|c|c|c|c|c|c}
\hline \hline Année & $\mathbf{9 3}$ & $\mathbf{9 4}$ & $\mathbf{9 5}$ & $\mathbf{9 6}$ & $\mathbf{9 7}$ & $\mathbf{9 8}$ & $\mathbf{9 9}$ & $\mathbf{0 0}$ & $\mathbf{0 1}$ & $\mathbf{0 2}$ & $\mathbf{0 3}$ & $\mathbf{0 4}$ & $\mathbf{0 5}$ & $\mathbf{0 6}$ \\
\hline \hline Primaire & 23.85 & 26.32 & 25.71 & 25.58 & 27.16 & 27.86 & 26.75 & 24.42 & 24.24 & 24.34 & 23.96 & 23.85 & 26.32 & 25.71 \\
\hline Secondaire & 37.41 & 35.71 & 33.98 & 32.34 & 33.75 & 31.91 & 35.18 & 39.73 & 35.65 & 35.20 & 33.77 & 37.41 & 35.71 & 33.98 \\
\hline Tertiaire & 38.74 & 37.97 & 40.31 & 42.08 & 39.09 & 40.23 & 38.07 & 35.86 & 40.11 & 40.47 & 42.27 & 38.74 & 37.97 & 40.31 \\
\hline Total & 100,0 & 100,0 & 100,0 & 100,0 & 100,0 & 100,0 & 100,0 & 100,0 & 100,0 & 100,0 & 100,0 & 100 & 100 & 100 \\
\hline Growth GDP & & 2.06 & 4.13 & 4.91 & 5.31 & 4.90 & 4.06 & 4.17 & 4.51 & 4.01 & 4.03 & 3.70 & 2.30 & 3.22 \\
\hline \hline
\end{tabular}

Source: National Accounts of Cameroon 
Table A2: Changes in employment by industry

\begin{tabular}{l|c|c|c|c|c|c|c|c|c|c|c||c||c||c}
\hline \hline Année & $\mathbf{9 3}$ & $\mathbf{9 4}$ & $\mathbf{9 5}$ & $\mathbf{9 6}$ & $\mathbf{9 7}$ & $\mathbf{9 8}$ & $\mathbf{9 9}$ & $\mathbf{0 0}$ & $\mathbf{0 1}$ & $\mathbf{0 2}$ & $\mathbf{0 3}$ & $\mathbf{0 4}$ & $\mathbf{0 5}$ & $\mathbf{0 6}$ \\
\hline \hline Secteur Primaire & 60.3 & 60.8 & 61.1 & 63.4 & 65.7 & 64.9 & 63.6 & 63.1 & 62.6 & 62.7 & 63.0 & 63.0 & 62.0 & 62 \\
\hline $\begin{array}{l}\text { Secteur } \\
\text { secondaire }\end{array}$ & 11.3 & 11.2 & 11.4 & 11.7 & 11.8 & 11.4 & 11.5 & 12.4 & 12.5 & 11.7 & 11.5 & 11 & 11 & 10 \\
\hline Secteur tertiaire & 28.4 & 28.0 & 27.5 & 24.9 & 22.6 & 23.6 & 24.8 & 24.5 & 24.9 & 25.6 & 25.6 & 26 & 27 & 28 \\
\hline Total & 100.0 & 100.0 & 100.0 & 100.0 & 100.0 & 100.0 & 100.0 & 100.0 & 100.0 & 100.0 & 100.0 & 100 & 100 & 100 \\
\hline \hline
\end{tabular}

Source: National Accounts of Cameroon.

Table A3: Changes in employment structure (in \%)

\begin{tabular}{l|c|c||c||c|c|c|c||c|c|c||c||c}
\hline \hline Year & $\mathbf{9 3}$ & $\mathbf{9 4}$ & $\mathbf{9 5}$ & $\mathbf{9 6}$ & $\mathbf{9 7}$ & $\mathbf{9 8}$ & $\mathbf{9 9}$ & $\mathbf{0 0}$ & $\mathbf{0 1}$ & $\mathbf{0 2}$ & $\mathbf{0 3}$ & $\mathbf{0 5}$ \\
\hline \hline Public sector & 6.2 & 6.0 & 5.6 & 4.6 & 4.0 & 3.7 & 3.6 & 3.5 & 3.1 & 2.8 & 2.8 & 4.9 \\
\hline Private sector & 93.8 & 94.0 & 94.4 & 95.4 & 96.0 & 96.3 & 96.4 & 96.5 & 96.9 & 97.2 & 97.2 & 95.1 \\
\hline Formal & 11.8 & 6.7 & 7.0 & 11.3 & 9.4 & 4.3 & 4.1 & 2.9 & 3.9 & 6.3 & 5.9 & 4.7 \\
\hline Informal & 88.2 & 93.3 & 93.0 & 88.7 & 90.6 & 95.7 & 95.9 & 97.1 & 96.1 & 93.7 & 94.1 & 90.4 \\
\hline Self-employment & 64.4 & 60.8 & 61.0 & 64.2 & 62.9 & 59.2 & 59.2 & 58.6 & 59.2 & 60.2 & 60.2 & - \\
\hline \hline
\end{tabular}

Source: National Accounts of Cameroon 1993 - 2003 and EESSI (2005)

Table A4: Technical efficiencies of sample firm

\begin{tabular}{|c|c|c|c|c|c|c|c|}
\hline \multicolumn{3}{|c|}{ From corrected model } & \multicolumn{4}{c|}{ From uncorrected model } \\
\hline Firm N & Technical efficiency & Firm $N^{\circ}$ & Technical efficiency & Firm $N^{\circ}$ & Technical efficiency & Firm N ${ }^{\circ}$ & Technical efficiency \\
\hline 1 & 0.1038 & 24 & 0.0672 & 1 & 0.1098 & 24 & 0.0688 \\
2 & 0.1664 & 25 & 0.1494 & 2 & 0.1528 & 25 & 0.1400 \\
3 & 0.0532 & 26 & 0.1405 & 3 & 0.0542 & 26 & 0.1480 \\
4 & 0.0781 & 27 & 0.0476 & 4 & 0.0704 & 27 & 0.0467 \\
5 & 0.1165 & 28 & 0.1293 & 5 & 0.1114 & 28 & 0.1276 \\
6 & 0.0943 & 29 & 0.1285 & 6 & 0.0957 & 29 & 0.1214 \\
7 & 0.0848 & 30 & 0.0441 & 7 & 0.0729 & 30 & 0.0435 \\
8 & 0.1050 & 31 & 0.0453 & 8 & 0.0961 & 31 & 0.0430 \\
9 & 0.1162 & 32 & 0.2304 & 9 & 0.1136 & 32 & 0.2091 \\
10 & 0.0336 & 33 & 0.1600 & 10 & 0.0336 & 33 & 0.1469 \\
11 & 0.1187 & 34 & 0.1526 & 11 & 0.1209 & 34 & 0.1477 \\
12 & 0.0628 & 35 & 0.0414 & 12 & 0.0590 & 35 & 0.0389 \\
13 & 0.0725 & 36 & 0.0804 & 13 & 0.0649 & 36 & 0.0761 \\
14 & 0.0606 & 37 & 0.1314 & 14 & 0.0559 & 37 & 0.1256 \\
15 & 0.0962 & 38 & 0.5774 & 15 & 0.0809 & 38 & 0.5723 \\
16 & 0.0429 & 39 & 0.1728 & 16 & 0.0381 & 39 & 0.1776 \\
17 & 0.0508 & 40 & 0.1054 & 17 & 0.0498 & 40 & 0.1055 \\
18 & 0.0412 & 41 & 0.1838 & 18 & 0.0439 & 41 & 0.1841 \\
19 & 0.3436 & 42 & 0.1340 & 19 & 0.3054 & 42 & 0.1253 \\
20 & 0.0689 & 43 & 0.1831 & 20 & 0.0767 & 43 & 0.2015 \\
21 & 0.1088 & 44 & 0.1101 & 21 & 0.1008 & 44 & 0.0948 \\
22 & 0.1625 & 45 & 0.0884 & 22 & 0.1511 & 45 & 0.0871 \\
23 & 0.0256 & & & 23 & 0.0216 & & \\
\hline Mean & & 0.1180 & & & & 0.1136 & \\
\hline
\end{tabular}

Source: Computed based on Survey and NIS data 